\title{
Impact of Service Quality, Customer Satisfaction and Switching Costs on Customer Loyalty
}

\author{
Do Thanh NGUYEN ${ }^{1}$, Van Thanh PHAM$^{2}$, Dung Manh TRAN 3 , Duyen Bich T. PHAM ${ }^{4}$ \\ Received: May 13, 2020 Revised: June 14, 2020 Accepted: July 09, 2020
}

\begin{abstract}
This study examines the relationships and the impacts of service quality, customer satisfaction and switching costs on customer loyalty of e-banking in commercial banks. This study uses questionnaires with 7-point Likert scale to collect data from 227 e-banking users, who are mainly students and paid employees in Hanoi City, Vietnam. The collected data are analyzed by using multivariate linear regression method. The results show that all five factors of service quality in e-banking - reliability, responsiveness, service capacity, empathy and tangibility have positive correlations with customer satisfaction. Among these determinants, service capacity and tangibility have the strongest impact. It means that, by increasing the quality of their services through five above factors, especially through improving capacity and tangibility, commercial banks can satisfy their customer better. In addition, customer satisfaction is strongly and positively correlated to customer loyalty. It means that, if customers are satisfied with e-banking services of one bank, they not only continue to do more businesses with this bank, but also recommend this bank to other people. Lastly, customer loyalty also has a strong and positive correlation with switching costs, which means customers tend to be loyal to one bank if the barriers to switching banks increase.
\end{abstract}

Keywords: E-banking, Customer Loyalty, Customer Satisfaction, Service Quality

JEL Classification Code: M10, M15, G21, N25

\section{Introduction}

Today, information technology has become one of the most important drivers of economy development. It has profoundly transformed many sectors of the economy and created hypercompetitive markets. In many industries,

${ }^{1}$ First Author. Senior Lecturer, Former Vice Rector, National Economics University, Vietnam. E-mail: thdoneu@yahoo.com

${ }^{2}$ Corresponding Author. Lecturer, National Economics University, Vietnam [Postal Address: No. 207 Giai Phong Street, Dong Tam

Ward, Hai Ba Trung District, Hanoi, 10000, Vietnam]

Email: vanpham.qtkd@gmail.com

${ }^{3}$ Associate Professor, National Economics University, Vietnam.

Email: manhdung@ktpt.edu.vn

${ }^{4}$ Dean of Banking, Finance and Business Administration Department,

Quy Nhon University, Vietnam.

Email: phamthibichduyen@qnu.edu.vn

(c) Copyright: The Author(s)

This is an Open Access article distributed under the terms of the Creative Commons Attribution Non-Commercial License (http://Creativecommons.org/licenses/by-nc/4.0/) which permits unrestricted noncommercial use, distribution, and reproduction in any medium, provided the original work is properly cited. like banking, the power has migrated from the producers and sellers to customers who can define what they want in terms of specific goods and services, prices, distribution channels, and even promotions (Calik \& Balta, 2006). As a result, in order to survive and develop in such competitive industry, each bank is not only required to increase their service quality, but also satisfy non-financial needs of the customers to remain their trust and loyalty (Hsu \& Nguyen, 2016).

According to Kolodinsky, Hogarth and Hilgert (2004), e-banking includes a wide ranges of different services, such as automatic teller machines (ATMs), direct transaction for bill payment, electronic money transfers, and so on. It is an increasingly important service in bank activities by providing more advantages than traditional bank distribution channels. E-banking allows customers to access their accounts anytime at anywhere with more complicated transactions, like housing loan, online trading and managing stock investment in a safer, faster and more convenient way.

In Vietnam, the trend of using e-banking services has a great potential development. According to The World Factbook, Vietnam ranks 14 out of 20 countries with the 
highest number of Internet users in the world in 2019. Internet banking services in Vietnam has increased 6.3 times over the past three years (Viet Nam News, 2018). However, many banks' customers are still cautious about using current offered e-banking services and worried about possible risks of safety, information security, fraud and technical issues. Cash on delivery (COD) is still the most popular payment method while $60 \%$ of merchants collect COD payment through self-delivery and shippers (Dang, 2020). Therefore, in order to retain current customers and stay competitive, it is important for the commercial banks in Vietnam to have a clear view on the impacts of their e-banking service quality, customer satisfaction, switching cost on customer loyalty.

In this study, we attempt to identify the determinants of service quality that affect customer satisfaction and loyalty, and the relationship between customer satisfaction and customer loyalty as well as between switching costs and customer loyalty, in the context of Vietnam. Based on this research results, commercial banks can identify the key determinants that affect their e-banking service quality. This identification, in turn, can enhance the competitiveness of commercials banks, effectively support the process of proactive international economic integration and improve the quality of Vietnamese's life.

\section{Literature Review}

\subsection{Service Quality of E-banking}

The first formal definition of e-service quality was provided by Zeithaml, Parasuraman and Malhotra (2000). According to this definition, e-service quality could be understood as a website that allows activities like shopping, purchasing and delivering products and services more efficiently and effectively. The meaning of service in this definition is comprehensive and it includes both pre- and post-electronic service aspects.

After analyzing 523 observations of e-banking, Jun and Cai (2001) identify a total of 17 dimensions of the Internet banking service quality, including (1) product variety/ diverse features, reliability, responsiveness, competence, courtesy, credibility, access, communication, customer understanding, collaboration, continuous improvement, content, accuracy, ease of use, timeliness, aesthetics, and security. The researchers believe that both Internetonly banks and traditional banks need to focus on three determinants: responsiveness, reliability, and access. In 2001, when studying the acceptance by Turkish customers of e-banking services, Polatoglu and Ekin (2001) have found three determinants that strongly affect to the quality of Internet banking services, including reliability, accessibility and saving.
Broderick and Vachirapornpuk (2002) use data of 160 observations, cited from 55 videos provided by a UK Internet banking website community, to build a service quality model of Internet banking. These researchers have identified five basic criteria that affect the way customers perceived service quality, including: (i) customers' expectation of the service, (ii) imagine and the reputation of service provider, (iii) aspects of service setting, (iv) the actual service encounter and (v) customer participation. The researchers also emphasize that two criteria, including service setting and customer participation, have the greatest impact on service evaluation. Sohail and Shanmugham (2003) study the customers' preferences for electronic banking and determinants that influence the adoption of e-banking. Through analyzing 300 respondents, the researchers find that the usage of e-banking in Malaysia is affected by the following determinants: computer accessibility, an awareness of e-banking, cost of using computer and internet, security level in transaction, the level of readiness to use services. The results of this research also shows that computer accessibility and the level of readiness to use services have significant impact on e-banking usage; while other determinants, including cost of using computer and internet, security level in transaction and Internet accessibility don't significantly affect the usage of e-banking.

Yousafzai, Pallistes and Foxall (2003) study the elements of trust and risk when using e-banking. A conceptual model of trust in e-banking usage has been suggested with two main antecedents, including perceived security and perceived privacy. The result of this study shows that customers' trust leads to positive intention of adopting e-banking. Yang and Fang (2004) state that the traditional criteria of evaluating service quality, such as competence, politeness, cleanliness, comfort and friendliness, are no longer suitable for online sales, while other criteria, including trust, responsibility, assurance, are important to both traditional and Internet services.

The research of Kolodinsky et al. (2004) explores determinants that affect the adoption of three e-banking technologies in USA, including ABP, phone banking and PC banking. This research hypothesizes that the ability to accept using e-banking service depends on these following determinants: (i) personal characteristics like personal income (current assess value, expected income in the future), age, marriage status, level of education, living area; (ii) features of e-Banking services like easyto-use awareness, relative advantages, usage process, distribution channels, compatibility, transaction risk and (iii) differences among e-banking technologies. The research has provided some important conclusions. Among indicators of personal characteristics: people who 
have higher income are more likely to use or going to use e-banking in next coming 12 months. People whose expected future income increases faster than current value are likely to use more phone banking and PC banking. People who own stock are more likely to use ABP and phone banking more. People who are over 65 have less ability to use phone banking and PC banking. Middleaged people are likely to use more PC banking than youngest customer group (under 35). Among indicators of e-banking characteristics, there are two indicators that have meaningful correlation and compatibility to all distribution channels of online banking.

Siu and Mou (2005) have adapted the dimensions of SERVQUAL to examine the service quality of e-banking in Hong Kong. Two researchers use factor analysis method to analyze four criteria, including credibility, usage efficiency, security and problem handling. The findings of this research show that two criteria, including security and efficiency, not only have significant impact on customer satisfaction but also lead to future consumption behavior. The research of Loonam and O'Loughlin (2008) has proposed 10 e-service dimensions that affect the service quality of e-banking in Ireland, including: web usability, security, quality of information, accessibility, trust, reliability, flexibility, responsiveness, self-recovery and personalization/ customization. Recently, Tabash, Albugami, Salim and Akhtar (2019) study the impact of e-banking service quality of Islamic banks on customer satisfaction in Saudi Arabia. Through analyzing 373 online users, the result of this study shows that reliability, responsiveness, ease-of-use and privacy/ security positively influences customer satisfaction. Among that, ease to use is considered to be the most important dimensions of online service quality in Islamic banks.

Trust is defined as a function of the level of risk, which is associated with e-banking transaction (Yousafzai et al, 2003). Therefore, since customers don't come to bank to make direct transactions, many studies of e-banking mainly focus on the trust of customers in bank (Polatoglu \& Ekin, 2001; Liao \& Cheung, 2002). The results of this research, like Usman (2015), show that customer's trust significantly influences on their decision of using bank services. In the area of service, trust is the confidence of customers that the service suppliers will achieve their needs (Anderson \& Weitz, 1989). With e-banking service, customers can make banking transaction anytime (24/7) and anywhere in a quick and convenient way. They don't have to go to the bank and all transactions are confirmed immediately (Wang, Lo, \& Hui, 2003). Therefore, the factors of bank service quality become an important driving force to increase customer satisfaction and strengthen customer loyalty.

\subsection{Hypotheses Design}

\subsubsection{Research Model}

The study uses the five-component model for service quality of Parasuraman, Zeithaml and Berry (1988) as a foundation model to identify determinants that affect e-banking services quality at commercial banks in Vietnam. Based on the literature review on service quality (in general) and on e-banking services (in particular), a research model has been developed for the following purposes. First, this study would analyze determinants that determine the quality of e-banking services. Then, the relationship between customer satisfaction and customer loyalty as well as between switching costs and customer loyalty will be examined in the context of Vietnamese commercial banking system (see Figure 1).

\subsubsection{Research Hypotheses}

\section{(i) The relationship between service quality and customer satisfaction}

There are many different concepts of customer satisfaction. However, in general, satisfaction can be associated with feelings of acceptance, happiness, relief, excitement, and delight (Hoyer \& MacInnis, 2001), or customer satisfaction is customers' evaluation of a product or service in terms of whether that product or service has met their needs and expectations (Zeithaml \& Bitner, 2003). Oliver (1993) has shown that satisfaction is the feeling of consumers when the consumption process satisfies their needs, expectations and goals in a pleasant and interesting way.

In general, these concepts have shown that satisfaction is a comparison between perceived reality and customers' expectations. Research on customer satisfaction often focuses on the expectation and cognitive abilities of customers (Krampf, Ueltschy, \& d'Amico, 2003). The level of satisfaction depends on the differences between actually perceived

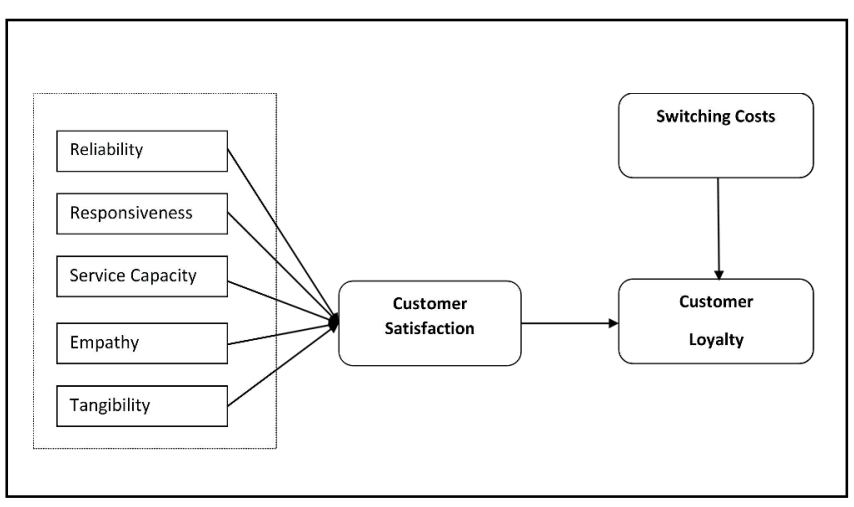

Figure 1: Proposed research model 
performance and expectation. If perceived performance is less than customer expectation, customers will be dissatisfied. If perceived performance is as equal as customer expectation, customers will be satisfied. If perceived performance is higher than customer expectation, then customers will be very satisfied. The service delivery process is the interaction among individuals, the efficiency or customer experience of the service. It is the interaction between customers and service providers that allows customers to assess service quality. Therefore, five hypotheses are proposed as below:

H1: Reliability has a positive effect on customer satisfaction.

H2: Responsiveness has a positive effect on customer satisfaction.

H3: Service capacity has a positive effect on customer satisfaction.

H4: Empathy has a positive effect on customer satisfaction.

H5: Tangibility has a positive correlation with customer satisfaction

(ii) The relationship between customer loyalty, customer satisfaction and switching costs

\section{Customer loyalty and customer satisfaction}

Theoretically, loyalty is proved to be one of the results of satisfaction, which has been mentioned in many studies. Whether customer satisfaction directly or indirectly contributes to customer loyalty though commitments, customer satisfaction is often proposed as the leading determinant of customer loyalty (Jackson, 1985; Bitner, 1990; Anderson \& Fornell, 1994). The study of Reichheld and Sasser (1990) shows that the cost of attracting a new customer is often five times higher than retaining an existing customer. And banks' profit is closely related to customer loyalty and customer retention. Therefore, banks must develop profitable long-term relationships with their customers in order to survive in a competitive retail banking environment. Trubik and Smith (2000) study the financial impact of customer retention and conclude that there is an intimate relationship between customer loyalty and profitability in retail banking industry. Customer loyalty is the property of enterprises in general and banks in particular.

In the service sector, service loyalty is the degree to which a customer exhibits repeat purchasing behavior with a service provider, possesses a positive attitude toward that provider, and considers using only this provider when they need (Gremler \& Brown, 1999). In the banking sector, loyalty means that after using a bank's service, customers continue to do more businesses with that bank and recommend it to other people. And if there is a need to use other services, that bank will be considered as the first choice even though customers know there may have a relatively better option at another bank (Khirallah, 2005).

In marketing materials, loyalty is perceived as the most important concept. Through many studies and contributions of loyalty approaches, we can see that there are two main streams of customer loyalty: behavioral aspects (Seiders, Voss, Grewall, \& Godfrey, 2005) and attitudinal aspects (Jacoby \& Chesnut, 1978). According to Gremler and Brown (1999), loyalty behavior refers to a repeat of purchasing goods/services of a brand over a long period of time, and a loyal attitude indicates customers' persistent preference or intention to purchase a brand's goods/services. According to Gronroos (1984), satisfaction leads to a strong relationship between providers and customers. When customer satisfaction grows to a higher level, it will result in customer loyalty.

H6: Customer satisfaction has a positive effect on customer loyalty.

\section{(iii) Switching costs and customer loyalty}

Jones, Mothersbaugh and Beatty (2002) have reported that switching barriers are any determinants that make customers feel it difficult or costly to change their suppliers, including the aspect of switching costs. Switching costs are customer's perception of time, money and effort related to changes in service providers or direct expenses that customers may spend to transit from one supplier to another (Ruyter, Wetzels, \& Bloemer, 1998). Gremler and Brown (1999) show that switching costs increase customer loyalty. The arising concerns of additional costs caused by switching suppliers have encouraged customers to maintain their relationships with current suppliers. For e-banking services, switching costs can be understood as service fees, procedures and time for new account registration, electronic banking registration and so on.

Once customers are satisfied with the quality of e-banking services, they are no longer interested in switching to another bank, because they are afraid of switching barriers that they may encounter when switching. Besides, during the interaction between banks and customers, it is customer satisfaction with e-banking service quality that plays as a barrier for customers to find new banks. Therefore, psychological barriers of switching service suppliers are often high (Arasil, 2005).

H7: Switching costs has a positive correlation with customer loyalty.

\section{Research Methods and Materials}

The study is carried out through the following specific steps: 
Step 1: Study theories, build a theoretical model and a system of research hypotheses.

Step 2: Design questionnaire for data collection. The questionnaire uses a 7-point Likert scale, with 1 for being completely disagreed/dissatisfied and 7 for being completely agreed/satisfied. The questionnaires are sent to customers of commercial banks in Vietnam in both hard copies and electronic versions.

Step 3: Examine research scale to assess its reliability and value as well as Cronbach's alpha coefficients

Step 4: Summarize research results through examining the model.

Step 5: Conclude and suggest recommendations.

\subsection{Research Sample}

In this study, the research subjects are customers of commercial banks. However, research samples will focus on students and paid employees. For students, university lecturers will support in sending questionnaires to class monitors and then these monitors will deliver questionnaires to members in their classes. For paid employees, questionnaires will be sent to them through the email database of banks. So, in general, there are two main subjects in this survey - students and paid employees. There are three reasons for choosing these two objects:

(i) Students and paid employees are those who have knowledge and understand the regulations of using e-banking services. In addition, students represent the youth who are dynamic, easy to update and interested in using new services with modern facilities.

(ii) Students and paid employees are regular e-banking users who usually make bank transactions and they are willing to use additional services.

(iii) Students and paid employees are also the first to use e-banking services launched by banks. They are capable to assess service quality and they want to use services with better quality.

Hanoi City is selected as the survey area because of its large population of residents and large needs for e-banking services. In fact, it is also one of the initial locations where banks launched their first e-banking service. In Hanoi, e-banking services have been implemented on a large scale and there are many related problems that need to be solved. Regarding service providers, in this study, the researchers have selected big banks such as Agribank, Vietinbank, BIDV, and Vietcombank. The information can also be gathered from other banks' customers.

Regarding the sample size, based on previous studies, the optimal sample size depends on these following determinants: the expectations of reliability, data analysis methods and estimation methods used in the study, and the estimated parameter and the structure of respondent groups. Specifically, according to Tabachnick and Fidell (2013), in order to have the best regression analysis, the sample size must follow the formula: $\mathrm{n}>=8 \mathrm{~m}+50$ ( $\mathrm{n}$ is the sample size, $\mathrm{m}$ is the number of independent variables in the model). According to Harris (2001), the sample size must follow the formula: $\mathrm{n}>=104+\mathrm{m}$ ( $\mathrm{m}$ is the number of independent and dependent variables) or $\mathrm{n}>=50+\mathrm{m}$ if $\mathrm{m}<5$. In case of applying Exploratory Factor Analysis EFA, Hair, Tatham and Black (1998) think that the minimum sample size must be 50 (it will be better if it is 100). Also, the ratio of observed/ measured variables is $5 / 1$, which means that each measurement variable needs a minimum of five observations. The research model has 26 measurement variables. Therefore, if the principle of five observations per measurement variable is followed, the minimum sample size is 130 observations.

\subsection{Data Collection Methods}

The research data are collected by questionnaires. Those questionnaires use the 7-point Likert scale with: "1 for being totally disagreed/dissatisfied, 2 for being disagreed/ dissatisfied, 3 for being a little disagreed/dissatisfied, 4 for being disagreed/dissatisfied and for not opposing, 5 for being slightly agreed/satisfied, 6 for being agreed/satisfied, 7 for being completely agreed/satisfied". Based on the research objectives, four potential variables are included in the research model, including: e-banking service quality, customer satisfaction, customer loyalty, and switching costs (Table 1).

\subsection{Data Analysis Method}

Data are analyzed by SPSS 20 software. This software is chosen for its simple use. Data collected from the questionnaire will be presented in Excel spreadsheets, then will be imported into SPSS 20 software for analysis.

Descriptive statistics such as mean, standard deviation, minimum, maximum of independent and dependent variables will be calculated. In addition, a correlation matrix between variables is also established. The model's regression results will be calculated and presented in tables.

To be able to perform regression, the first thing to do is shortening the variables. Data collected from the questions can be shortened in many different ways. It is common to use the Exploratory Factor Analysis method to reduce determinants into variables to conduct regressions. However, this study uses available variables (scales) based on the results of previous studies, so, in order to shorten variables, we can use the average method. Accordingly, each variable will be calculated according to the mean of items. Those means will not diminish the representativeness of variables (Bagozzi $\&$ Heatheaton, 1994). Therefore, there are eight shortened 
Table 1: Research Scale

\begin{tabular}{|c|c|c|}
\hline Code & Variables and Its attributes & Source \\
\hline $\mathrm{TC}$ & Reliability & \multirow{22}{*}{$\begin{array}{l}\text { Parasuraman et al } \\
\qquad(1988)\end{array}$} \\
\hline TC1 & The bank keeps its promises. & \\
\hline TC2 & The bank provides e-services on time as its commitment. & \\
\hline TC3 & $\begin{array}{l}\text { If there is any arising problem with e-banking services, the bank always cares } \\
\text { about solving it. }\end{array}$ & \\
\hline DU & Responsiveness & \\
\hline DU1 & Bank staff let me know exactly when my transactions are made. & \\
\hline DU2 & Bank staff always provide advisory services to me & \\
\hline DU3 & Bank staff never show that they are too busy to comply with customer requirements & \\
\hline PV & Service capacity & \\
\hline PV1 & The behavior of bank staff increases customer trust. & \\
\hline PV2 & Customer feels safe when using e-banking services & \\
\hline PV3 & Bank staff is always polite and courteous. & \\
\hline PV4 & Bank staff is knowledgeable to answer your questions. & \\
\hline DC & Empathy & \\
\hline DC1 & Bank staff has their customers' best interests at heart & \\
\hline $\mathrm{DC} 2$ & Bank staff always understands the needs of customers. & \\
\hline DC3 & Bank staff gives customer their individual attention. & \\
\hline DC4 & $\begin{array}{l}\text { Bank support department operates hours convenient to achieve all customers' } \\
\text { needs }\end{array}$ & \\
\hline $\mathrm{HH}$ & Tangibility & \\
\hline $\mathrm{HH} 1$ & The Bank's website gives me valuable information. & \\
\hline $\mathrm{HH} 2$ & The Bank's website allows me to find information easily. & \\
\hline $\mathrm{HH} 3$ & The Bank's website has an eye-catching interface. & \\
\hline TM & Customer satisfaction & \multirow{4}{*}{ Liu, Guo and Lee (2011) } \\
\hline TM1 & Overall, I am satisfied with the service offered by the Bank. & \\
\hline TM2 & Overall, I am satisfied with e-transaction offered by the bank & \\
\hline TM3 & Overall, I am satisfied with the bank. & \\
\hline TT & Customer loyalty & \multirow{4}{*}{$\begin{array}{c}\text { Liu et al. (2011); } \\
\text { Parasuraman et al } \\
\text { (1988) }\end{array}$} \\
\hline TT1 & I will continue to make e-banking transactions with the bank. & \\
\hline TT2 & The bank has always been my first choice for my e-banking transactions. & \\
\hline TT3 & I would recommend the Bank to my friends and relatives. & \\
\hline CD & Switching costs & \multirow{4}{*}{ Liu et al. (2011) } \\
\hline CD1 & It will take a long time if I make e-banking transactions at another bank. & \\
\hline CD2 & The cost will be high if I make e-banking transactions at another bank. & \\
\hline CD3 & $\begin{array}{l}\text { It will be difficult for me to be familiar with the electronic banking transaction } \\
\text { procedures of a new bank. }\end{array}$ & \\
\hline
\end{tabular}

and named variables, including: (1) TC: Reliability; (2) DU: Responsiveness; (3) PV: Service capacity; (4) DC: Empathy; (5) HH: Tangibility; (6) TM: Customer satisfaction; (7) TT: Customer loyalty; (8) CD: Switching costs.

This study uses the multiple regression model to analyze the determinants that affect independent variables. To analyze the relationship between independent and dependent variables, the following regression equations are used:
(1) The regression equation for the relationship between customer satisfaction and e-banking service quality is as follows:

$$
T M=\beta_{0}+\beta_{1} T C+\beta_{2} D U+\beta_{3} P V+\beta_{4} D C+\beta_{5} H H+e_{i}
$$

(2) The regression equation for the relationship between customer loyalty and customer satisfaction is as follows: 
$T T=\beta_{0}+\beta_{1} T M+e_{i}$

(3) The regression equation for the relationship between customer loyalty and bank switching costs is as follows:

$$
T T=\beta_{0}+\beta_{1} C D+e_{i}
$$

\section{Results and Discussion}

\subsection{Descriptive Statistics}

The research samples are collected from customers of commercial banks in Vietnam. A total of 227 customers are interviewed through paper and online questionnaires (using online links to questionnaire). These research samples have some basic statistical characteristics as follows:

Gender: there are 114 males (50.2\%) and 113 females (49.8\%) among 227 respondents.

Age: there are 100 respondents under 20 years old $(48.5 \%), 51$ respondents from 21 to 30 years old $(22.5 \%), 40$ respondents from 31 to 40 years old $(17.6 \%), 16$ respondents from 41 to 50 years old $(7.1 \%)$ and 10 respondents over 50 years old $(4.3 \%)$. Therefore, the respondents are mainly from under 20 to 40 years old. This age group is suitable as this age group includes people who prefer to use modern technology, therefore, they tend to use e-banking service most frequently.

Income: regarding to monthly income, there are 96 respondents with income below VND10 million (42.3\%), 77 respondents with income from VND10 to 20 million $(33.9 \%), 42$ respondents with income from VND20 to 30 million $(18.5 \%)$, eight respondents with income from VND30 to 40 million (3.5\%), three respondents with income from VND40 to 50 million (1.3\%) and one respondent with income over VND50 million $(0.5 \%)$. Therefore, the majority of respondents have income from under VND10 to 20 million. This is the common income of Vietnamese people.

Academic level: regarding to academic level, there are 45 respondents with high school degree (19.8\%), 168 respondents with university/ college degree (74\%), 14 respondents with postgraduate degree (6.2\%). Therefore, the majority of respondents have university/ college degree or higher, which means they are able to access information technology and use e-banking service.

Time of using e-banking services: there are 42 users with less than 1 year $(18.5 \%), 47$ users with $1-2$ years of use $(20.7 \%), 68$ users with 2-3 years of use (30\%), 35 users with 3-4 years of use (15.4\%), 14 users with 4-5 years of use $(6.2 \%)$ and 31 users with over 5 years of use $(9.2 \%)$. This is consistent with the reality of Vietnam as the e-banking services are recently developed and the majority of Internet users have usage time around 2-3 years.
E-banking services and products: regarding to services and products of e-banking that are provided to customers, the research shows that Vietnamese customers mainly use e-banking services for the following purposes: checking account information (86\%), money transfer $(70 \%)$, interpersonal payment (57\%), bill payment (29\%), and credit card (19\%) (see Table 2).

Therefore, the statistics shows that the majority of customers use e-banking services for three main reasons - checking account information, money transfer, and interpersonal payment. The usage of other services, like securities trading, bill payment and credit card, are still limited.

\subsection{Testing the Reliability of Research Scale}

In order to test the reliability of research scale, we apply Cronbach's Alpha coefficient. This method allows researchers to remove inappropriate variables, limit spam variables during research process and assess the reliability of research scale by Cronbach's Alpha coefficient. Variables with item-total correlation that is smaller than 0.3 will be removed. Scales with Cronbach Alpha coefficient that is 0.6 and higher can be used with new research concept. (Slater, 1995). Normally, scale with Cronbach's Alpha from 0.7 to 0.8 can be used. Many researchers believe that the best scale would have Cronbach's Alpha coefficient from 0.8 to nearly 1. After calculating Cronbach's Alpha coefficients, all Alpha coefficients are larger than 0.6 , which means it is reliable enough to run the model (see Table 3 ).

\subsection{Regression Analysis}

\subsubsection{The Correlation between Service Quality and Customer Satisfaction}

In order to evaluate the effect of e-banking service quality to customer satisfaction, the multivariate linear regression method has been used. The regression results are as follows:

$$
\begin{aligned}
T M= & 0.017+0.169 T C+0.139 D U+0.289 P V+0.166 D C \\
& +0.258 H H+e_{i}
\end{aligned}
$$

In addition, from the standardized regression coefficients (Gujarati \& Porter, 2009), there are two determinants that have strongest impact on customers' satisfaction, including service capacity (PV) and tangibility $(\mathrm{HH})$ with the standardized coefficient of 0.27 and 0.219 , respectively. This is the foundation for the bank to improve the service quality of e-banking to satisfy their customers' requirements. Besides that, based on the sign of regression coefficients and t-values (or Sig. values), we can conclude that all five proposed hypotheses are statistically significant at 5\% confidence level (Sig value $<5 \%$ ), therefore, the five hypotheses are accepted. 
The results of ANOVA analysis show that statistical value $\mathrm{F}=58.696$, with $\mathrm{Sig} .=0.000<5 \%$; therefore, all five independent variables in the model have impact on dependent variables. (Gujarati, 2009). Based on the model suitability

Table 2: Used products and service of E-Banking

\begin{tabular}{|l|c|c|}
\hline \multicolumn{1}{|c|}{ Types of services } & Quantity & Percentage (\%) \\
\hline $\begin{array}{l}\text { Checking account } \\
\text { information }\end{array}$ & 159 & $70 \%$ \\
\hline Interpersonal payment & 113 & $49.8 \%$ \\
\hline Broker & 1 & $0.4 \%$ \\
\hline Instalment payment & 3 & $1.3 \%$ \\
\hline Bill payment & 21 & $9.3 \%$ \\
\hline Money transfer & 198 & $87.2 \%$ \\
\hline Credit & 29 & $12.8 \%$ \\
\hline Credit card & 36 & $15.9 \%$ \\
\hline Certificate of Deposit & 18 & $7.9 \%$ \\
\hline Securities Trading & 6 & $2.6 \%$ \\
\hline
\end{tabular}

Table 3: Summary of Cronbach's Alpha coefficient of variables

\begin{tabular}{|c|l|c|}
\hline No & \multicolumn{1}{|c|}{ Variables } & Cronbach's Alpha \\
\hline 1 & Reliability & 0.761 \\
\hline 2 & Responsiveness & 0.665 \\
\hline 3 & Service capacity & 0.790 \\
\hline 4 & Empathy & 0.845 \\
\hline 5 & Tangible & 0.702 \\
\hline 6 & Customer Satisfaction & 0.871 \\
\hline 7 & Customer Loyalty & 0.906 \\
\hline 8 & Switching Costs & 0.815 \\
\hline
\end{tabular}

standards suggested by Gujarati and Porter (2009), the research model is highly relevant to explain the behavior of dependent variables.

The results of regression analysis also show that five determinants (five independent variables of this mode) can explain $57 \%$ of the variation of the dependent variables. This implies that this model has high level of interpretation and relevance. Therefore, according to regression results, all five hypotheses are accepted. It means that all five determinants of service quality of e-banking affect customer satisfaction. The signs of all five hypotheses are positive, which proves that commercial banks can improve their customer satisfaction by improving their service quality. There are two determinants that have strongest impact, including service capacity and tangibility. This is the orientation for commercial banks to quickly increase their customer satisfaction (see Table 4).

\subsubsection{The Correlation between Customers' Loyalty, Customer Satisfaction and Switching Costs}

Attracting customers plays a significantly important role in bank competition. Therefore, evaluating the correlation between customer loyalty, customer satisfaction and switching costs is needed to propose suitable solutions to have more customers. The results of regression analysis of the correlation between customer loyalty, customer satisfaction and switching costs are shown in the following equation:

$$
T T=0.610+0.673 T M+0.254 \mathrm{CD}+e_{i}
$$

The results of regression analysis show that both customer satisfaction (TM) and switching costs (CD) have positive effect on customer loyalty. Especially, from regression coefficients, customer satisfaction variable has a strong correlation to customer loyalty (with beta is 0.673 ). It means that commercial banks can remain their customer

Table 4: The Regression Results of Model 1

\begin{tabular}{|c|c|c|c|c|c|c|}
\hline & \multirow[t]{2}{*}{ Model } & \multicolumn{2}{|c|}{$\begin{array}{l}\text { Unstandardized } \\
\text { Coefficients }\end{array}$} & \multirow{2}{*}{$\begin{array}{c}\text { Standardized } \\
\text { Coefficients } \\
\text { Beta } \\
\end{array}$} & \multirow[t]{2}{*}{$\mathbf{T}$} & \multirow[t]{2}{*}{ Sig. } \\
\hline & & B & Std. Error & & & \\
\hline \multirow{6}{*}{1} & (Constant) & .017 & .345 & & .049 & .961 \\
\hline & $\mathrm{TC}$ & .169 & .056 & .168 & 3.035 & .003 \\
\hline & DU & .139 & .067 & .134 & 2.073 & .039 \\
\hline & PV & .289 & .072 & .270 & 3.995 & .000 \\
\hline & $\mathrm{DC}$ & .166 & .061 & .174 & 2.716 & .007 \\
\hline & $\mathrm{HH}$ & .258 & .062 & .219 & 4.160 & .000 \\
\hline
\end{tabular}


Do Thanh NGUYEN, Van Thanh PHAM, Dung Manh TRAN, Duyen Bich T. PHAM/

Journal of Asian Finance, Economics and Business Vol 7 No 8 (2020) 395-405

Table 5: The Regression Results of Model 2

\begin{tabular}{|c|c|c|c|c|c|c|}
\hline \multirow{2}{*}{\multicolumn{2}{|c|}{ Model }} & \multicolumn{2}{|c|}{ Unstandardized Coefficients } & \multirow{2}{*}{$\frac{\text { Standardized Coefficients }}{\text { Beta }}$} & \multirow{2}{*}{$\mathbf{t}$} & \multirow{2}{*}{ Sig. } \\
\hline & & B & Std. Error & & & \\
\hline \multirow{3}{*}{2} & (Constant) & .601 & .378 & & 1.592 & .113 \\
\hline & TM & .673 & .061 & .569 & 11.068 & .000 \\
\hline & $C D$ & .254 & .055 & .235 & 4.579 & .000 \\
\hline
\end{tabular}

loyalty by increasing their customer satisfaction. In addition, switching costs also positively impact on customer loyalty. It means that customers tend to be loyal to one bank if the switching costs among different banks increase. Therefore, both hypotheses $\mathrm{H} 4$ and $\mathrm{H} 5$ are accepted at the statistical significance of $5 \%$ (with Sig. value $<5 \%$ ).

The results of ANOVA analysis show that statistical value $\mathrm{F}=93.895$, with Sig. $=0.000<5 \%$; therefore, we can conclude that both two independent variables in the model impact on dependent variables (Gujarati, 2009). Based on the standards of model suitability suggested by Gujarati and Porter (2009), the research model is highly relevant to explain the behavior of dependent variables. The regression analysis results show that two determinants (two independent variables of the mode) can explain $45.6 \%$ of the variation of the dependent variables. This implies that this model has high level of interpretation and relevance (see Table 5).

\section{Conclusions}

Firstly, according to the results, all five determinants of e-banking service quality have positive correlation with customer satisfaction. Several studies (Parasuraman et al, 1985; Jun \& Cai, 2001; Siu \& Mou, 2005; Pikkarainen, Pikkarainen, Karjaluoto \& Pahnila, 2006; Tran, 2020) support this conclusion. It means that commercial banks can increase their customers' satisfaction by increasing their service quality. Among these determinants, service capacity and tangibility have the strongest impact on customer satisfaction. This is the orientation for commercial banks to propose suitable strategies to improve the satisfaction level of their customers.

Secondly, the regression analysis results also show that customer satisfaction and customer loyal have a positive and strong correlation. It means that if one customer satisfies with the e-banking services of one bank, they not only continue their business with this bank, but also introduce this bank to other customers. This result is consistent with the results of Jun and Cai (2001); Siu and Mou (2005) and so on.

Lastly, customers' loyalty has a positive correlation with switching costs. This correlation is quite strong, which means customers tend to be loyal with one bank if the barriers caused by switching costs among banks increase. This result is similar to the findings of Jones et al. (2002), Ruyter et al. (1998), Gremler and Brown (1996). However, this result is different from the research results of Tran and Pham (2015), which conclude that there is no correlation between switching costs and customer loyalty in the context of Vietnam.

\section{References}

Anderson, E.W., \& Fornell, C. (1994). A customer satisfaction research prospectus. In Rust, R.T. \& Oliver, R.L. (Eds.). Service Quality: New Directions in Theory and Practice. Thousand Oaks, CA: Sage Publications.

Anderson, E., \& Weitz, B. (1989). Determinants of continuity in conventional industrial channel dyads. Marketing Science, 8(4), 310-323. https://doi.org/10.1287/mksc.8.4.310

Arasil, O. (2005). Customer loyalty and the effect of switching costs as a moderator variable a case in the Turkish mobile phone market. Marketing Intelligence \& Planning, 23(1), 89-103.

Bagozzi, R.P., \& Heatherton T.F (1994). A General Approach for Representing Multifaceted Personality Constructs: Application to State Self-Esteem. Structural Equation Modeling, 1(1), 3567. https://doi.org/10.1080/10705519409539961.

Bitner, M.J. (1990). Evaluating service encounters: The effects of physical surroundings and employee responses. Journal of Marketing, 54(2), 69-82.

Broderick, A. J., \& Vachirapornpuk, S. (2002). Service quality in Internet banking: The importance of customer role. Marketing Intelligence \& Planning, 20(6), 327-335. https://doi. org/10.1108/02634500210445383

Calik, N., \& Balta, N.F. (2006). Consumer satisfaction and loyalty derived from the perceived quality of individual banking services: A field study in Eskisehir from Turkey. Journal of Financial Services Marketing, 10(4), 135-149.

Dang, H.L. (2020). Vietnam's booming E-commerce Market. ISEAS Yusof Ishak Institute, 2020 (4), 1-3. ISSN 2335-6677.

Gremler, D.D., \& Brown, S.W. (1999). The loyalty ripple effect: appreciating the full value of customers. International Journal of Service Industry Management, 10(3), 271-291.

Gronroos, C. (1984). A Service Quality Model and Its Marketing Implications. European Journal of Marketing, 18, 36-44.

Gujarati, D.N. (2009). Basic econometrics. New Delhi, India: Tata McGraw-Hill Education 
Gujarati, D., \& Porter, D.C. (2009). Basic Econometrics (5 $5^{\text {th }}$ ed.). New York, NY: McGraw-Hill

Hair, J.F., Tatham, R.L., \& Black, W. (1998). Multivariate Data Analysis $(5 t h$ ed.). Upper Saddle River, NJ: Prentice Hall International, Inc.

Harris, R.J. (2001). A primer of multivariate statistic (3rd ed.). Mahwah, NJ: Lawrence Erlbaum.

Hsu, Yi \& Nguyen, M. (2016) Service quality, customer satisfaction, and customer loyalty of Internet Banking in Vietnam. International Review of Management and Business Research, 5(4), 1485-1496

Hoyer, W.D., \& MacInnis, D.J. (2001). Consumer Behavior (2nd ed.). Boston, MA: Houghton Mifflin Company; 2011.

Jackson, B. B. (1985). Build Customer Relationships that Last. Harvard Business Review, 63, 120-128.

Jacoby, J., \& Chestnut, R.W. (1978). Brand Loyalty: Measurement and Management ( $1^{\text {st }}$ ed.). New York, NY: John Wiley \& Sons.

Jones, A., Mothersbaugh, L., \& Beatty, E. (2002). Why customers stay: measuring the underlying dimensions of services switching costs and managing their differential strategic outcomes. Journal of Business Research, 55(6), 441-450. https://doi.org/10.1016/S0148-2963(00)00168-5

Jun, M., \& Cai, S. (2001). The key determinants of internal banking service quality: a content analysis. International Journal of Bank Marketing, 19(7), 276-91.

Khirallah, K. (2005). Customer Loyalty in Retail Banks: Time to Move beyond Simple Programs or a Product Orientation. View Point Issue 127. Tower Group.

Kolodinsky, J. M., Hogarth, J. M., \& Hilgert, M.A. (2004). The adoption of electronic banking technologies by US consumer. The International Journal of Bank Marketing, 22(4), 238-259.

Krampf, R., Ueltschy, L. \& d'Amico, M. (2003). The contribution of emotion to consumer satisfaction in the service setting. Marketing Management Journal, 13, 32-52.

Liao, Z. \& Cheung, M.T. (2002). Internet-Based e-Banking and Consumer Attitudes: An Empirical Study. Information \& Management, 39, 283-295.

Liu, C. T., Guo, Y. M., \& Lee, C.H. (2011). The Effects of Relationship Quality and Switching Barriers on Customer Loyalty. International Journal of Information Management, 31, 71-79.

Loonam, M., \& O'Loughlin, D. (2008). Exploring e-service quality: a study of Irish online banking. Marketing Intelligence \& Planning, 26(7), 759-780.

Oliver, R. L. (1993). A conceptual model of service quality and service satisfaction: Compatible goals, different concepts. Advances in Services Marketing and Management, 2, 65-85.

Parasuraman, A., Zeithaml, V.A., \& Berry, L.L. (1985). A conceptual model of service quality and its implications for future research. Journal of Marketing, 49(4), 41-50.
Parasuraman, A., Zeithaml, V. A., \& Berry, L.L. (1988). SERVQUAL: a multiple-item scale for measuring consumer perception of service quality. Journal of Retailing, 64, 12-40.

Pikkarainen, K., Pikkarainen, T., Karjaluoto, H., \& Pahnila, S. (2006). The measurement of end-user computing satisfaction of online banking services: Empirical evidence from Finland. International Journal of Bank Marketing, 24(3), 158-172. DOI: $10.1108 / 02652320610659012$

Polatoglu, V. N., \& Ekin, S. (2001). An empirical investigation of the Turkish consumers' acceptance of Internet banking service. International Journal of Bank Marketing, 19(4), 156-165.

Reichheld, F., \& Sasser, W.E.J. (1990). Zero defections: quality comes to services. Harvard Business Review, 68(5), 105-11.

Ruyter K., Wetzels, M., \& Bloemer, J. (1998). On the relationship between perceived service quality, service loyalty and switching costs. International Journal of Service Industry Management, $9(5), 436-453$.

Seiders, K., Voss, G. B., Grewal, D., \& Godfrey, A. L. (2005). Do satisfied customers buy more? Examining moderating influences in a retailing context. Journal of Marketing, 69, 26-43.

Siu, N. Y. M., \& Mou, J.C.W. (2005). Measuring service quality in Internet banking: The case of Hong Kong. Journal of International Consumer Marketing, 17(4), 99-116. https://doi. org/10.1300/J046v17n04_06

Slater, S. (1995). Issues in Conducting Marketing Strategy Research. Journal of Strategic Marketing, 3(4), 257-270. https://doi.org/10.1080/09652549500000016

Sohail, M.S., \& Shanmugham, B. (2003). E-banking and customer preferences in Malaysia: An empirical. Information Science, 150, 207-217.

Tabachnick, B.G., \& Fidell L.S. (2013). Using Multivariate Statistics $\left(6^{\text {th }}\right.$ ed.). Pearson Education, Inc.

Tabash, M.I, Albugami, M.A., Salim, M. \& Akhtar, A. (2019). Service quality dimensions of E-retailing of Islamic Banks and Its impact on customer satisfaction: An empirical investigation of Kingdom of Saudi Arabic. Journal of Asian Finance, Economics and Business, 6(3), 225-234. https://doi. org/10.13106/jafeb.2019.vol6.no3.225.

The World Factbook (2020). Country Comparison: Internet Users. Retrieved January 10, 2020 from: https:/www.cia.gov/library/ publications/the-world-factbook/fields/204rank.html

Tran, V.D. (2020). Assessing the Effects of Service Quality, Experience Value, Relationship Quality on Behavioral Intentions. Journal of Asian Finance, Economics and Business, 7(3), 167-175. https://doi.org/10.13106/jafeb.2020.vol7. no3.167

Tran, D.T., \& Pham, L. (2013). The relationship between e-banking service quality, customer satisfaction and customer loyalty in Vietnam. Journal of Economics and Development, 195, 26-33. 
Trubik, E., \& Smith, M. (2000). Developing a model of customer defection in the Australian banking industry. Managerial Auditing Journal, 15(5), 199-208.

Usman, H. (2015). Customers Trust on Islamic bank in Indonesia. Journal of Asian Finance, Economics and Business, 2(1), 5-13. https://doi.org/10.13106/jafeb.2015.vol2.no1.5.

Viet Nam News (2018). Vietnamese banks take advantage of digital era. Viet Nam News. Retrieved November 03, 2018, from https://vietnamnews.vn/economy/469030/vietnamese-bankstake-advantage-of-digital-era.html

Wang, Y., Lo, H., \& Hui, Y.V. (2003). The antecedents of service quality and product quality and their influences on bank reputation: Evidence from banking industry in China. Managing Service Quality, 13(1), 72-83.
Yang, Z., \& Fang, X. (2004). Online service quality dimensions and their relationships with satisfaction: A content analysis of customer reviews of securities brokerage services. International Journal of Service Industry Management, 15(3), 302-326.

Yousafzai, S.Y., Pallistes, J.G., \& Foxall, G.D. (2003). A Proposed Model of e-Trust for Electronic Banking', Technovation, 23, 847-860.

Zeithaml, V. A, Parasuraman, A., \& Malhotra, A. (2000). E-service Quality: Definition, Dimensions and Conceptual Model. Marketing Science Institute Working Paper, Cambridge, MA: Marketing Science Institute.

Zeithaml, V. A., \& Bitner, M. J. (2003). Services Marketing (6 $6^{\text {th }}$ ed.). New York, NY: McGraw-Hill Education. 